\title{
ANNOUNCEMENTS
}

\section{FINLAND BRINGS A CASE AGAINST DENMARK}

The following information has been made available by the Registry of the International Court of Justice (Communiqué No. 91/14, 17 May 1991):

On 17 May 1991 the Republic of Finland filed in the Registry of the Court an Application instituting proceedings against the Kingdom of Denmark in respect of a dispute concerning the question of passage of oil-rights through the Great Belt (Store Baelt - one of the three straits linking the Baltic to the Kattegat and thence to the North Sea).

In its Application Finland contends that there is no foundation in international law for the unilateral exclusion by Denmark, through the projected construction of a 'high-level bridge, 65 metres above main sea level', of the passage between the Baltic and the North Sea by vessels such as drill ships and oil rigs or other existing or reasonably foreseeable ships with a height of 65 metres or above to and from Finnish shipyards and ports. Such exclusion allegedly violates Finland's rights in respect of free passage through the Great Belt as established in the relevant conventions and customary international law. Finland recognizes that Denmark is fully entitled, as the territorial sovereign, to take measures to improve its internal and international traffic connections, but contends that Denmark's entitlement to take such measures is necessarily limited by the established rights and interests of all States, and of Finland in particular, in the maintenance of the legal regime of free passage through the Danish straits. In Finland's view, these rights have been ignored by Denmark's refusal to enter into negotiations with Finland in order to find a solution and by its insistence that the planned bridge project be completed without modification.

Accordingly, the Republic of Finland, reserving its right to modify or to add to its submissions and in particular its right to claim compensation for any damage or loss arising from the bridge project, asks the Court to adjudge and declare:

'(a) That there is a right of free passage through the Great Belt which applies to all ships entering and leaving Finnish ports and shipyards;

(b) That this right extends to drill ships, oil rigs and reasonably foreseeable ships;

(c) That the construction of a fixed bridge over the Great Belt as currently planned by Denmark would be incompatible with the right of passage mentioned in subparagraphs (a) and (b) above; 
(d) That Denmark and Finland should start negotiations, in good faith, on how the right of free passage, as set out in subparagraphs (a) to (c) above shall be guaranteed.'

Finally, Finland announces that it will shortly file a request for provisional measures in accordance with Article 41 of the Statute of the Court.

\section{CASE CONCERNING PASSAGE THROUGH THE GREAT BELT (FINLAND v. DENMARK) - FIXING OF TIME-LIMITS}

In a further communique (No. 91/25 of 29 July 1991) the Registry of the International Court of Justice communicated the following:

In the case concerning Passage through the Great Belt (Finland v. Denmark) brought before the Court by the Republic of Finland on 17 May 1991, the President of the Court, by an Order of 29 July 1991, has fixed the following timelimits in the written proceedings:

- 30 December 1991 for the Memorial of the Republic of Finland;

- 1 June 1992 for the Counter-Memorial of the Kingdom of Denmark. The subsequent procedure is reserved for further decision. 